\title{
lodine Level of Salt and Associated Factors at Household Level in Gidami District, Oromia Region, Ethiopia: A Cross-Sectional Study
}

This article was published in the following Dove Press journal: Nutrition and Dietary Supplements

\author{
Abulu Waga Dinka' \\ Tadesse Kebebe ${ }^{2}$ \\ Girma Nega' \\ 'Department of Applied Human \\ Nutrition, Bahir Dar University, Bahir \\ Dar, Ethiopia; ${ }^{2}$ Food Science and \\ Nutrition Research Directorate, \\ Ethiopian Public Health Institute, Addis \\ Ababa, Ethiopia
}

Purpose: Iodine deficiency disorders remain a major public health problem globally, and more than a quarter of the world's population is affected by this micronutrient deficiency. The problem is even worse in developing countries including Ethiopia, and the government has been implementing globally recommended universal salt iodization as one strategy to control iodine deficiency disorders. The objective of this study was to assess iodine content of salt used in households, and associated factors.

Methods: A community-based cross-sectional study was conducted from February to June, 2017 in Gidami district, Western Ethiopia. A total of 470 household food caterers participated in the study by using random sampling method. Data were collected using interviewer administered questionnaire and rapid iodized salt test kit to assess socio-demographic characteristics, knowledge, practices and iodine content of the salt. Bivariate and multivariate logistic regressions were used to identify associated factors of iodine level in the salt using odds ratio with $95 \%$ confidence interval.

Results: Among the household salt samples, $83.6 \%$ were found to be iodized ( $>0 \mathrm{ppm})$ while $29.8 \%$ (95\% CI: $25.8,33.9 \%$ ) were found to be adequately iodized. Respondents who had formal education $[\mathrm{AOR}=1.82,95 \% \mathrm{CI}:(1.42,3.53)]$, had an occupation [AOR=4.78, 95\% CI: (1.55-14.73)], did not expose salt to sunlight [AOR=1.13, 95\% CI: $(1.10-1.27)$ ] had good knowledge of iodized salt $[\mathrm{AOR}=1.184,95 \% \mathrm{CI}$ : $(1.103,1.328)]$, and had good practice regarding iodized salt $[\mathrm{AOR}=1.32,95 \% \mathrm{CI}:(1.717,2.442)]$ were more likely to have adequately iodized salt at household level.

Conclusion: According to this study, the availability of adequately iodized salt at household level was below global and national target of universal iodine utilization. This study suggested the importance of paying more attention to availability of iodine fortification and increasing awareness regarding the importance of iodized salt and potential factors such as utilization practice and handling of iodized salt.

Keywords: iodine, iodized salt, Gidami district, Ethiopia

\section{Introduction}

Iodine is necessary for the production of the thyroid hormone called thyroxin, which is essential to control growth, repair damaged cells, and support a healthy metabolism. ${ }^{1}$ Iodine deficiency disorders (IDDs) prevent normal growth in the brain, nervous system and lead to poor school performance, reduced intellectual ability and impaired work capacity. Pregnant women and children under five are mainly at risk of developing IDD. ${ }^{1-3}$
Correspondence: Abulu Waga Dinka Department of Applied Human Nutrition, Bahir Dar University, Bahir Dar 79. Ethiopia

Email abulu.waga@bdu.edu.et

Nutrition and Dietary Supplements 2021:13 9-16 
Iodine deficiency disorder is a major public health concern affecting an estimated 2 billion people worldwide. ${ }^{1}$ According to World Health Organization's report, the problem is even worse in developing countries where 350 million Africans live at risk of iodine deficiency and about $28 \%$ have goiters. ${ }^{2,4}$

In spite of efforts to eliminate iodine deficiency, Ethiopia is still among the high-risk iodine-deficient countries in East Africa. ${ }^{5}$ According to national micronutrient survey (MNS, 2016) 48\% of school aged children and $52 \%$ of reproductive aged women had mean urinary iodine concentration below the cutoff. The national average goiter rate among reproductive aged women was $10.8 \%$, which indicates that goiter prevalence rate remains of significant public health importance. ${ }^{5,6}$

Universal salt iodization (USI) is the most feasible recommended strategy globally to control iodine deficiency, which is adding iodine to universally consumed products such as common salt, to be available for all populations. ${ }^{1,4,7}$ The Ministry of health in Ethiopia is implementing universal salt iodization, including mandatory use and sale of iodized salt as part of national nutrition program to eliminate iodine deficiency disorders in Ethiopia. ${ }^{8}$

Even though more than $70 \%$ of all households had access to adequately iodized salt, it less than $50 \%$ in 39 developing countries. ${ }^{2}$ Similarly, due to few efficient iodization facilities and improper utilization, only $26 \%$ of the households were getting adequately iodized salt in Ethiopia, while World Health Organization recommends $90 \%$ coverage of iodized salt is needed to eliminate IDD. ${ }^{1,6}$

Several studies have been carried out on availability of adequately iodized salt and associated factors at household level in different parts of Ethiopia. Those previous studies revealed that factors such as educational status, occupation status, exposing salt to sunlight, storage and knowledge of utilization were associated with availability of adequately iodized salt at household level. ${ }^{5,9-13}$

Apart from other areas, no study has mentioned availability of adequately iodized salt and related factors in Gidami district as an effort of national salt iodization program and promoting consumption of iodized salt to reduce iodine deficiency disorders. Therefore, this study assessed the availability of adequately iodized salt at household level and associated factors in the district.

\section{Materials and Methods}

\section{Study Area and Design}

Community based cross-sectional study was conducted from February 2017 to March 2017 in Gidami District, Western Ethiopia. The district is found in kelem welega zone, Oromia region, $738 \mathrm{Km}$ away from Addis Ababa. The study area is divided into 30 villages and has a total population of 106,907 and 14,292 households.

\section{Inclusion and Exclusion Criteria}

Household members who were eligible for interview (those who are mostly involved in food preparation and 18 years old and above) were included.

\section{Study Population and Sample Size}

Sample size was calculated using single population proportion formula by assuming the prevalence of iodized salt users in western Oromia was $17 \%$ from a survey conducted in 2014. Therefore sample size of 476 households was taken by assumption of $95 \%$ confidence interval, $5 \%$ absolute precision, design effect of two and 10\% nonresponse rate.

\section{Sampling Procedures}

Among 30 villages in the district, eight were selected by stratified simple random sampling and total sample size was allocated for each selected village proportional to their number of households. Then, systematic random sampling technique was employed to select each study household (Figure 1).

\section{Study Variables and Measurements}

Availability of adequately iodized salt at household level was a dependent variable while socio-demographical characteristics and factors affecting the concentration of iodine in the iodized salt and use of iodized salt at household level were independent variables in this study.

Rapid iodized salt test kit was used in the survey to assess iodine content of salt in the households. To assess the iodine content, the color of the salt was compared with a chart $\left(0,<15\right.$, and $\geq 15$ parts per million, ppm). ${ }^{3}$ Iodine level of salt was labeled as adequate when tested with rapid test and the level was $15 \mathrm{ppm}$ or more and inadequate when less than $15 \mathrm{ppm}$.

With regards to awareness and practices, participants were asked IDD knowledge questions (proper utilization and advantage of consuming iodized salt) and those who 


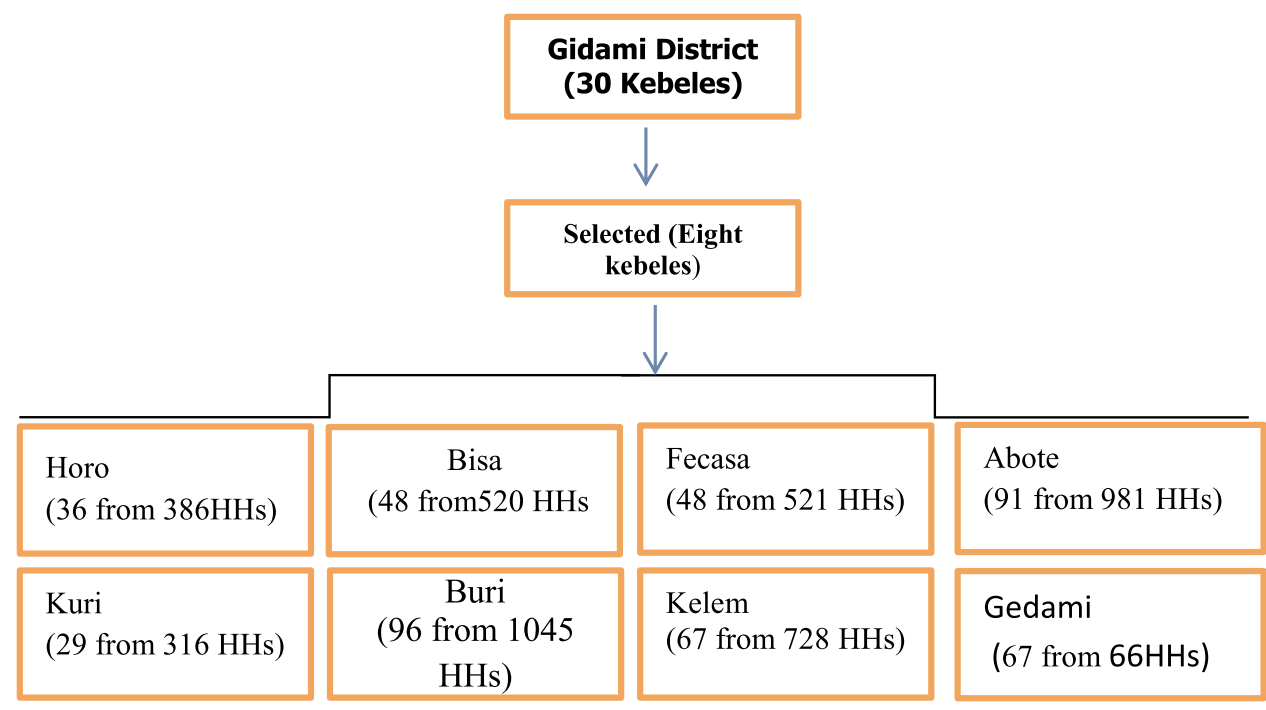

Figure I Diagram representing sampling procedures.

scored $\geq 50 \%$ were considered as having good knowledge. Respondents with any single practice that might result in the reduction of salt iodine content were labeled to have improper practice, whereas, participants who stored the purchased salt for more than two months were considered as having longer storage time, and those who stored for less than two months were considered as having shorter storage time.

\section{Data Collection Procedures and Quality Control}

The questionnaire consists of socio-demographic characteristics, knowledge and practice of iodized salt and was developed in English based on review of earlier similar studies. ${ }^{10,14-17}$ Then data collection was done after the questionnaire was translated to local language and checked for validity. Three trained nurses (nursing diploma) and one health extension (as facilitators) from each selected village were hired, trained and used for data collection. After data collection, each data set collected was checked for completeness and consistency on a daily basis.

\section{Data Processing and Analysis}

The collected data were cleaned, coded, and entered into EPI-INFO and analyzed using the Statistical Package for the Social Sciences (SPSS) version 20. Data were summarized using descriptive statistics. The association between single dependent and dependent variable was observed through bivariate analysis and then, variables with p-value less than 0.2 were included in the multiple logistic regression analysis to identify factors associated with iodine content of salt. For all statistical significance tests between each independent and dependent variable, significance level was fixed at $\mathrm{P}$-value $<0.05$ and $95 \%$ confidence interval.

\section{Results}

\section{Socio-Demographic Characteristics}

A total of 470 food caterers were interviewed, which was $98.7 \%$ response rate. The mean age of the respondents was $36.4 \pm 12.1$ years while majority $(454,[96.6 \%])$ of the respondents were female and Christian (407, [86.6\%]). From study participants, about 421 (89.6\%) were married and more than half $(261,[55.6 \%])$ had attended or completed elementary school or more. Additionally, 322 $(68.5 \%)$ of the respondents were farmers (occupational status) (Table 1).

\section{lodine Content of Household Salt}

As seen from Table 2, among salt collected from households for testing, 393 (83.6\%) had different levels of iodine while the rest $(77,[16.4 \%])$ tested as $0 \mathrm{ppm}$. Among this, 140 (29.8\%) had adequate iodine levels $(\geq$ $15 \mathrm{ppm})$ while $253(53.8 \%)$ were inadequately iodized as shown by rapid test kits. Around 297 (63.2\%) of the respondents were using common salt (coarse salt without plastic package or unpacked salt) of which $245(82.5 \%)$ were inadequately iodized salt.

Thirty seven percent of the households used packed salt or original salt packages and out of it around 89 
Table I Socio-Demographic Characteristics of Respondents, Gidami Districts, 2017

\begin{tabular}{|c|c|c|c|}
\hline \multicolumn{2}{|l|}{ Variables } & \multirow{3}{*}{$\begin{array}{l}\text { Frequency } \\
454 \\
16\end{array}$} & \multirow{3}{*}{$\begin{array}{l}\text { Percent (\%) } \\
96.6 \\
3.4\end{array}$} \\
\hline Sex & Female & & \\
\hline & Male & & \\
\hline \multirow[t]{3}{*}{ Ethnicity } & Oromo & 466 & 99.2 \\
\hline & Amhara & 3 & 0.7 \\
\hline & Gurage & 1 & 0.1 \\
\hline \multirow[t]{3}{*}{ Religion } & Orthodox & 205 & 43.6 \\
\hline & Protestant & 202 & 43 \\
\hline & Muslim & 63 & 13.4 \\
\hline \multirow[t]{5}{*}{ Age } & $18-24$ & 53 & 11.3 \\
\hline & $25-34$ & 209 & 44.5 \\
\hline & $35-44$ & 112 & 23.8 \\
\hline & $45-54$ & 61 & 13 \\
\hline & $55 \geq$ & 35 & 7.4 \\
\hline \multirow[t]{3}{*}{ Marital status } & Married & 421 & 89.6 \\
\hline & Single & 19 & 4 \\
\hline & Widowed & 30 & 6.4 \\
\hline \multirow[t]{5}{*}{ Educational status } & Cannot read and write & 144 & 30.6 \\
\hline & Can read and write only & 65 & 13.8 \\
\hline & Grades I-8 & 179 & 38.1 \\
\hline & Grades 9-12 & 46 & 9.8 \\
\hline & Above secondary school & 36 & 7.7 \\
\hline \multirow[t]{5}{*}{ Occupation } & Farmer & 322 & 68.5 \\
\hline & Merchant & 51 & 10.9 \\
\hline & Government employee & 36 & 7.7 \\
\hline & Housewife & 34 & 7.4 \\
\hline & Others & 27 & 5.5 \\
\hline
\end{tabular}

(50.9\%) were adequately iodized salt. Majority of the packed salt users got it from open market and about 385 (81.9\%) stored salt $\leq 2$ months after purchasing it. The main reasons mentioned for not using packed iodized salt were not being familiar with using iodized salt and lack of awareness about iodized salt $(264,[56.2 \%])$ whereas half $(238,[50.6 \%])$ of study participants had good practices (Table 2).

\section{Knowledge of lodized Salt}

The majority of food caterers $(305,[64.9 \%])$ responded that they had never heard of iodized salt and $290(61.7 \%)$ had good knowledge of iodized salt. Some (133, [28.3\%]) of the caterers had no knowledge of the benefits of iodized salt while more than half $(238,[50.6 \%])$ replied that the benefits of iodized salt related to preventing goiter. Only 5
(1.1\%) of the food caterers responded that the benefits of iodized salt related to growth and development (Table 3).

\section{Factors Associated with the Availability of Adequately lodized Salt at Household Level}

This study tried to find factors associated with availability of adequately iodized salt at household level using bivariate and multivariable logistic regression model. Thus, having formal education, good knowledge about iodized salt, duration of storage, place purchased, occupation, sunlight exposure, types of salt, and good practice regarding iodized salt were found to be associated with availability of adequately iodized salt in the bivariate logistic regression. However, in the multivariable logistic regression; educational status, knowledge about iodized salt, practice, 
Table 2 Availability and Practice of Food Caterers Regarding the Use of lodized Salt at Household Level, Gidami District, 2017

\begin{tabular}{|c|c|c|c|}
\hline \multicolumn{2}{|l|}{ Variables } & \multirow{3}{*}{$\begin{array}{l}\text { Frequency } \\
264 \\
206\end{array}$} & \multirow{3}{*}{$\begin{array}{l}\text { Percent (\%) } \\
56.2 \\
43.8\end{array}$} \\
\hline Place where salt is purchased & Open market & & \\
\hline & Shop & & \\
\hline \multirow[t]{2}{*}{ Types of salt } & Packed salt & 173 & 36.8 \\
\hline & Non packed salt & 297 & 63.2 \\
\hline \multirow[t]{3}{*}{ Place of storage } & Dry place & 224 & 47.7 \\
\hline & Moisture area & 87 & 18.5 \\
\hline & Fire/heat area & 159 & 33.8 \\
\hline \multirow[t]{2}{*}{ Exposure to sun light } & Yes & 91 & 19.3 \\
\hline & No & 379 & 80.7 \\
\hline \multirow[t]{2}{*}{ Duration of salt storage at household level } & $\leq 2$ months & 385 & 81.9 \\
\hline & $>2$ months & 85 & 18.1 \\
\hline \multirow[t]{3}{*}{ Level of iodine in salt at household level } & $\geq 15 p p m$ & 140 & 29.8 \\
\hline & $<15 p p m$ & 253 & 53.8 \\
\hline & Oppm & 77 & 16.4 \\
\hline \multirow[t]{4}{*}{ Reason for not using packed salt } & More expensive than common salt & 112 & 23.9 \\
\hline & Lack of awareness & 264 & 56.2 \\
\hline & Difficulty to obtain & 82 & 17.5 \\
\hline & Less salty or has bitter taste & 12 & 2.4 \\
\hline \multirow[t]{2}{*}{ Practice } & Good & 238 & 50.6 \\
\hline & poor & 232 & 49.4 \\
\hline
\end{tabular}

Table 3 Source of Information and Knowledge of Food Caterers Regarding the Importance of lodized Salt in Gidami District, 2017

\begin{tabular}{|l|l|l|l|}
\hline \multicolumn{2}{|l|}{ Variables } & Frequency & Percent (\%) \\
\hline Heard about iodized salt & Yes & 305 & 64.9 \\
& No & 165 & 35.1 \\
\hline \multirow{2}{*}{ Importance of iodized salt } & Prevent goiter & 238 & 50.6 \\
& Prevent IDD & 68 & 14.5 \\
& To stay healthy & 26 & 5.5 \\
& To grow well & 5 & 1.1 \\
& Do not know & 133 & 28.3 \\
\hline Knowledge & Good & 290 & 61.7 \\
& Poor & 180 & 38.3 \\
\hline
\end{tabular}

sunlight exposure, and employment status were associated with the availability of adequately iodized salt (Table 4).

Accordingly, those who had good knowledge about iodized salt were 1.2 times more likely to have adequately iodized salt than those who had poor knowledge $[\mathrm{AOR}=1.18,95 \% \mathrm{CI}$ : $(1.103,1.328)]$. In addition, those who had formal education were 1.8 times more likely to have adequately iodized salt in the household than those who had no formal education
[AOR $=1.82$, 95\% CI: (1.42, 3.53)]. Regarding occupational status of the food caterers, those who were employed were 4.8 times more likely to have adequately iodized salt than merchants [AOR=4.78, 95\% CI: (1.55-14.73)].

Although, respondents who had good practice regarding iodized salt utilization were 1.3 times more likely to have adequately iodized salt than those who had poor practice $[\mathrm{AOR}=1.32$, 95\% CI: $(1.717,2.442)]$. Similarly, 
Table 4 Factors Associated with Availability of Adequately lodized Salt at Household Level ( $\geq 15 p p m)$ in Gidami District, 2017

\begin{tabular}{|c|c|c|c|c|}
\hline \multirow[t]{2}{*}{ Variables } & \multicolumn{2}{|c|}{ Frequency } & \multirow{2}{*}{$\begin{array}{l}\text { Crude OR } \\
(95 \% \mathrm{Cl})\end{array}$} & \multirow{2}{*}{$\begin{array}{l}\text { Adjusted OR } \\
(95 \% \mathrm{CI})\end{array}$} \\
\hline & $\geq 15 p p m$ & <15ppm & & \\
\hline \multicolumn{5}{|l|}{ Educational level } \\
\hline Formal education & 104(39.8) & $157(60.2)$ & $3.18[2.06-4.92]^{*}$ & $1.82[1.42-3.53]^{*}$ \\
\hline No formal education & $36(17.2)$ & $173(82.8)$ & I & 1 \\
\hline \multicolumn{5}{|l|}{ Occupation } \\
\hline Farmer & $66(20.5)$ & $256(79.5)$ & $0.29[0.15-0.49]^{*}$ & $0.69[0.32-1.47]$ \\
\hline Housewife & $15(42.9)$ & $20(57.1)$ & $0.78[0.33-1.85]$ & $0.97[0.38-2.47]$ \\
\hline Merchant & $25(49)$ & $26(5 \mathrm{I})$ & 1 & \\
\hline Employed & $3 I(86 . I)$ & $5(13.9)$ & $6.45[2.16-19.23]^{*}$ & $4.78[1.55-14.73]^{]}$ \\
\hline Other & $3(\mid 2.5)$ & $27(87.5)$ & $0.15[0.02-1.29]^{*}$ & $0.28[0.03-2.61]$ \\
\hline \multicolumn{5}{|l|}{ Types of salt used } \\
\hline Packed salt & $88(50.90)$ & $85(49.10)$ & $4.88[3.19-7.44]^{*}$ & $1.66[0.91-3.03]$ \\
\hline Non packed salt & $52(17.5)$ & $245(82.5)$ & 1 & 1 \\
\hline \multicolumn{5}{|l|}{ Duration of salt storage } \\
\hline$>2$ months & $17(19)$ & $68(81)$ & $0.49[0.28-0.89]^{*}$ & $0.93[0.46-1.88]$ \\
\hline$\leq 2$ months & $124(32.2)$ & $26 \mid(67.8)$ & 1 & I \\
\hline \multicolumn{5}{|l|}{ Exposure to sunlight } \\
\hline Yes & $18(19.8)$ & $73(80.2)$ & 1 & 1 \\
\hline No & $122(32.2$ & $257(67.8)$ & $1.93[1.10-3.37]^{*}$ & $1.13[1.10-1.27]^{*}$ \\
\hline \multicolumn{5}{|l|}{ Knowledge } \\
\hline Good & $106(36.6)$ & $184(63.4)$ & $2.47[1.59-3.85]^{*}$ & $1.18[1.10-1.33]^{*}$ \\
\hline Poor & $34(18.9)$ & $146(8 \mid .1)$ & 1 & 1 \\
\hline \multicolumn{5}{|c|}{ Place where salt is purchased } \\
\hline Open market & $43(16.3)$ & $22 I(83.7)$ & $0.39[0.24-0.65]^{*}$ & $0.59[0.32-1.01]$ \\
\hline Shop & $40(33.1)$ & $8 I(66.9)$ & 1 & 1 \\
\hline Pharmacy & $57(67.1)$ & $28(32.90)$ & $4.12[2.28-7.44]^{*}$ & $2.03[0.98-4.18]$ \\
\hline \multicolumn{5}{|l|}{ Practice } \\
\hline Good & $75(64.1)$ & $163(46.2)$ & $2.08[|.35-3.2|]^{*}$ & $1.32[1.72-2.44]^{*}$ \\
\hline Poor & $42(35.9)$ & $190(53.8)$ & 1 & 1 \\
\hline
\end{tabular}

Note: *P-value is significant at $\alpha<0.05$.

Abbreviations: OR, odds ratio; $\mathrm{Cl}$, confidence interval.

those who did not expose salt to sunlight were 1.1 times more likely to have adequately iodized salt than those who exposed it to sunlight [AOR=1.13, 95\% CI: $(1.10-1.27)]$.

\section{Discussion}

The national guideline for control and prevention of micronutrient deficiencies in Ethiopia are targeted to eliminate IDD through universal salt iodization because it is a major public health problem. ${ }^{8}$ The present study's result showed that $29.8 \%$ (95\% CI: $25.8,33.9 \%$ ) of households had adequately iodized salt, and factors like educational status, knowledge about iodized salt, practice, sunlight exposure, and employment status were associated with the availability of adequately iodized salt.

The observed percentage was similar to prevalence of national nutrition survey (26\%), ${ }^{6}$ study done in Gondar town $(28.9 \%)^{10}$ and Kenya $(26.2 \%),{ }^{19}$ while greater than a study done in Beni Shangul-Gumuz Region (18.5\%). ${ }^{18}$ However, the prevalence of iodized salt utilization in this study was lower than in studies conducted in North West Ethiopia (33.2\%), $(40 \%),{ }^{9,16} 2016$ EDHS (89\%), ${ }^{20}$ South Sudan $(72.9 \%)^{21}$ and Uganda $(50.5 \%){ }^{7}$ The difference might be due to market availability, accessibility and level of awareness in each study area and country. 
Regarding factors associated with availability of iodized salt in the households, educational status of respondents was among the associated factors. This result is aligned with studies done in Kenya, ${ }^{19}$ Ghana $^{22}$ and south west Ethiopia. ${ }^{14}$ This might be due to the fact that education can change and increase the decision making of individuals.

Besides this, exposure to sun light was another factor affecting availability of iodized salt at household level, similar to studies done in Wolaita, Gondar, south wollo, Kazakhstan, and London. ${ }^{11,12,17,23}$ This might be due to level of awareness among respondents from each study area.

In addition, practice of food caterers and knowledge of respondents about iodized salt were significantly associated with availability of adequately iodized salt at household level in this study. This finding is consistent with studies conducted in other parts of the country like; Addis Ababa, Southern, South western and Gondar town. ${ }^{14,17,24,25}$ Another study conducted in Ghana also mentioned there had been an increase in the consumption rate of iodized salt from increased knowledge and practice regarding the importance of using iodized salt. $^{26}$

\section{Conclusion}

In conclusion, availability of iodized salt at household level was far lower than the target recommended by WHO (greater than $90 \%$ of households). ${ }^{3}$ From our finding, improved educational status, good knowledge of iodized salt, good practice regarding iodized salt, minimizing sunlight exposure, and employment status were found to be associated factors. Therefore we recommended intervention to improve households' level of iodized salt based on this evidence and additional study focused on market availability and accessibility of iodized salt.

\section{Abbreviations}

AOR, adjusted odds ratio; CI, confidence interval; COR, crude odds ratio; EDHS, Ethiopian Demographic and Health Survey; IDDs, iodine deficiency disorders; ppm, parts per million; SD, standard deviation.

\section{Data Sharing Statement}

The datasets used and/or analyzed during the current study can be obtained from the corresponding author on reasonable request.

\section{Ethics Approval and Consent to Participate}

To ensure ethical procedure, ethical clearance was obtained from Ethical Clearance Committee of Faculty of Chemical and Food Engineering, Bahir Dar University. Permission letter was obtained from the district health office and all study participants were informed of the purpose of the study and provided written informed consent. All the procedures to conduct this study followed the Helsinki declaration of human research.

\section{Acknowledgments}

The authors wish to acknowledge Bahir Dar University for funding this study and all participants who were involved in this study during data collection.

\section{Author Contributions}

All authors made a significant contribution to the work reported, starting from conception, study design, execution, acquisition of data, analysis and interpretation, took part in drafting, revising or critically reviewing the article; gave final approval of the version to be published; have agreed on the journal to which the article has been submitted; and agree to be accountable for all aspects of the work.

\section{Funding}

Bahir Dar University, Institute of technology funded the required budget for data collection. The funder had no role in the design, data collection, analysis and interpretation, manuscript preparation and publication of this study.

\section{Disclosure}

The authors declare that they have no competing interests.

\section{References}

1. World Health Organization. Guideline: Fortification of Food-Grade Salt with Iodine for the Prevention and Control of Iodine Deficiency Disorders. Geneva, Switzerland: WHO; 2014.

2. UNICEF. Sustainable Elimination of Iodine Deficiency. New York: UNICEF; 2008:1-29.

3. World Health Organisation. Assessment of the Iodine Deficiency Disorders and Monitoring Their Elimination. Geneva: WHO; 2007:1-107.

4. WHO, FAO. Guidelines on Food Fortification with Micronutrients. Geneva: WHO and FAO; 2006.

5. Gebretsadikan TM, Troen AM. Progress and challenges in eliminating iodine deficiency in Ethiopia: a systematic review. BMC Nutr. 2016;2 (1):1-12. doi:10.1186/s40795-016-0051-0

6. Ethiopia Public Health Institute. National micronutrient survey,survey report. 2016. 
7. Knowles JM, Garrett GS, Gorstein J, et al. Household coverage with adequately iodized salt varies greatly between countries and by residence type and socioeconomic status within countries: results from 10 national coverage surveys. J Nutr. 2017;147(5):1004S1014S. doi:10.3945/jn.116.242586

8. Republic. National Nutrition Programme Republic of Ethiopia. 2015.

9. Abebe Z, Tariku A, Gebeye E. Availability of adequately iodized in Northwest Ethiopia: a cross-sectional study. Arch Public Heal. 2017;75(1):1-9.

10. Yaye AB, Baraki N, Endale BS. Availability of adequately iodized salt at household level and associated factors in Dire Dawa, Eastern Ethiopia. Int J Public Heal Sci. 2016;5(4):392.

11. Kumma WP, Haji Y, Abdurahmen J, Mehretie Adinew Y. Factors affecting the presence of adequately iodized salt at home in Wolaita, Southern Ethiopia: community based study. Int J Food Sci. 2018;2018:1-9. doi:10.1155/2018/4394908

12. Mekonnen TC, Eshete S, Wasihun Y, et al. Availability of adequately iodized salt at household level in Dessie and Combolcha Towns, South Wollo, Ethiopia. BMC Public Health. 2018;18:1152. doi:10.1186/s12889-018-6066-5

13. Town H, Girma M, Loha E, et al. Original article Iodine deficiency in primary school children and knowledge of iodine deficiency and iodized salt among caretakers in 2009.

14. Takele L, Belachew $\mathrm{T}$, Bekele $\mathrm{T}$. Iodine concentration in salt at household and retail shop levels in Shebe town, South West Ethiopia. East Afr Med J. 2003;80(10):532-539. doi:10.4314/eamj. v80i10.8757

15. Gerensea H, Yohannse A, Baymot B, Atsbha H, Nguse K, Gebru L. Knowledge, attitude and practice (KAP) towards iodized salt utilization in HaweltiKebelle. Edorium J Nutr Diet Edorium J Nutr Diet Edorium J Pathol [Internet]. 2016;222(March):1-81.

16. Girma K, Nibret E, Gedefaw M. The status of iodine nutrition and iodine deficiency disorders among school children in Metekel Zone, northwest Ethiopia. Ethiop J Health Sci. 2014;24(2):109-116. doi:10.4314/ejhs.v24i2.2
17. Gebremariam HG, Yesuf ME, Koye DN. Availability of adequately iodized salt at household level and associated factors in Gondar Town, Northwest Ethiopia. ISRN Public Health. 2013;2013:1-6. doi: $10.1155 / 2013 / 160582$

18. Sahilu Assegid TWG. Cross-sectional survey of goiter prevalence and household salt iodization levels in Assosa Town, Beni Shangul-Gumuz Region, West Ethiopia. J Pregnancy Child Heal. 2014;01(03):1-6.

19. Kazungu K, Mbakaya C, Makokha A, Diseases I. Factors contributing to iodide deficiency in coast Province of. 2015;3(2):45-51.

20. Central Statistical Agency. Ethiopia Demographic and Health Survey, Addis Ababa, Ethiopia. Calverton, Maryland, USA: ICF International; 2016.

21. Gaffar AM, Mahfouz MS. Peace impact on health: population access to iodized salt in south Sudan in post-conflict period. Croat Med J. 2011;52(2):178-182. doi:10.3325/cmj.2011.52.178

22. Clement Ahiadeke. Factors influencing the use of adequately iodated salt in Ghana. African J Food Sci. 2012;6:3. doi:10.5897/AJFS11.177

23. Waszkowiak K, Szymandera-Buszka K. Effect of storage conditions on potassium iodide stability in iodised table salt and collagen preparations. Int $J$ Food Sci Technol. 2008;43(5):895-899. doi:10.1111/j.1365-2621.2007.01538.x

24. Bazezew MM, Yallew WW, Belew AK. Knowledge and practice of iodized salt utilization among reproductive women in Addis Ababa City. BMC. 2018;11(1):1-8.

25. Haji Y, Abdurahmen J, Paulos W. Knowledge and perception of consumption of iodized salt among food handlers in Southern Ethiopia. Food Nutr Bull. 2017;38(1):92-102. doi:10.1177/ 0379572116684909

26. Appiah PK, Fenu GA, Yankey FWM. Iodine content of salt in retail shops and retailers' knowledge on iodized salt in Wa East District, Upper West Region, Ghana. J Food Qual. 2020;2020.
Nutrition and Dietary Supplements

\section{Publish your work in this journal}

Nutrition and Dietary. Supplements is an international, peerreviewed, open access journal focusing on research into nutritional requirements in health and disease, impact on metabolism and the identification and optimal use of dietary strategies and supplements necessary for normal growth and development. The journal welcomes submitted papers covering original research, basic science,

\section{Dovepress}

clinical \& epidemiological studies, reviews and evaluations, guidelines, expert opinion and commentary, case reports and extended reports. The manuscript management system is completely online and includes a very quick and fair peer-review system, which is all easy to use. Visit http://www.dovepress.com/testimonials.php to read real quotes from published authors. 